\title{
Somatic Genome Editing for Health: Disease Treatments and Beyond
}

\author{
Tetsuya Ishii ${ }^{1}$
}

Published online: 3 October 2016

(C) Springer International Publishing AG 2016

\begin{abstract}
Genome editing has facilitated versatile gene modifications in somatic and stem cells. Despite the early stage, therapeutic uses of ZFN and TALEN have already demonstrated promising results in the treatment of HIV and leukemia. Although the medical conditions to which genome editing therapy is applied are being expanded in the clinical trials, it is currently unclear whether regulatory authorities will approve genome editing therapy in the near future. Moreover, the widespread use of CRISPR/ Cas9, in particular, is likely to lead to clinically unproven disease treatments. Furthermore, genome editing might be used for gene doping or cosmetic treatments. This article discusses the prospects of somatic genome editing for health purposes, while briefly reviewing the relevant clinical trials. Moreover, some potential ethical issues arising from the widespread use of genome editing are considered to discuss how genome-editing medicine might be appropriately integrated into the global society.
\end{abstract}

Keywords Genome editing - Disease treatment - Gene doping - Cosmetic treatment - Ethics - Global society

This article is part of the Topical Collection on Ethics in Stem/Progenitor Cell Therapeutics

Tetsuya Ishii

tishii@general.hokudai.ac.jp

1 Office of Health and Safety, Hokkaido University, Sapporo, Hokkaido 060-0808, Japan

\section{Introduction}

There are still many medical conditions that are difficult to treat with drugs. Therapies using stem cell transplantation or gene transfer may provide fundamental treatments by regenerating functional cells or restoring gene expression in patients. Among such treatments, allogenic hematopoietic stem cell (HSC) transplantation is the most widely used in the clinical setting [1]. However, the feasibility of HSC transplantation depends on the availability of human leukocyte antigen (HLA)-matched donors. Using HSCs derived from a partially HLA-mismatched donor might lead to graft-versushost disease (GVHD) [2]. The therapeutic use of autologous somatic and stem cells, including mesenchymal stem cells (MSCs), is another strategy [3]. In the case of genetic disease, autologous cell transplantation necessitates prior gene correction. However, gene correction via homologous recombination has, for the most part, been largely inefficient in human stem cells $[4,5]$. Cell therapy involving gene transfer in vitro is also referred to as ex vivo gene therapy. In vivo gene therapy intends to directly deliver a wild-type (WT) gene into target cells in a patient. Although gene transfer is frequently carried out using a viral vector, retroviruses are associated with the risk of insertional mutagenesis and adenovirus (Ad) vectors that may cause an inflammatory response [6].

In genome editing, zinc-finger nucleases (ZFNs) [7], transcription activator-like effector nucleases (TALENs) [8], and the clustered regularly interspaced short palindromic repeat (CRISPR)/Cas $9[9,10]$ can be used to perform efficient gene insertion, correction, and disruption in human somatic and stem cells. Genome editing can also simultaneously modify multiple sites across the genome (multiplex genome editing) [11]. Genome editing has already been integrated into gene therapies. In 2014, a phase 1 study reported that the infusion of autologous CD4+T cells in which the CCR5 gene was 
disrupted by ZFN treatment was safe in patients with HIV infection [12••]. In 2015, TALEN-mediated T cell receptor (TCR) gene disruption was performed in chimeric antigen receptor (CAR) 19 T cells. The infusion of genetically modified CAR19 T cells resulted in no GVHD symptoms in a special therapy for a patient with B cell acute lymphoma leukemia (ALL) [13]. Multiple clinical trials involving genome editing are currently ongoing, and the number of medical conditions to which it is applied is expanding.

Researchers have developed stem cell and gene therapies so that these modalities can be effective for a prolonged period of time. Ironically, regulatory authorities review stem and gene therapies more rigorously than more traditional, chemical drugs, for which risk assessment has been well established based on absorption, distribution, metabolism, and excretion (ADME) $[3,14,15]$. Then, how will regulators view genome editing therapy? The social integration of genome-editing medicine is another question - as with the diffusion of genome editing in clinical settings; the genetic engineering will likely be provided without clear grounds for its application or for nontherapeutic purposes.

This article herein argues the prospect of genome editing medicine and briefly reviews the ongoing clinical trials. In order to appropriately integrate genome-editing medicine into society, some potential ethical issues arising from its potential widespread uses are also considered. This article focuses on the clinical uses of ex vivo and in vivo somatic genome editing [14], not germ line genome editing, which is associated with more profound ethical, legal, and social issues [16].

\section{The History of Gene Therapy}

Before examining the current developments in genome editing therapy, it is worth revisiting the history of gene therapy. The first clinical trial in the USA in 1990 aimed to develop ex vivo gene therapy for an orphan disorder, adenosine deaminase severe combined immune deficiency (ADASCID) [17]. The therapy, which involved the infusion of autologous T cells into which WT ADA had been transferred with a retroviral vector, was a partial success. To date, at least 2210 clinical trials of gene therapy have been carried out in at least 34 countries (Fig. 1). The vast majority of the trials were performed in the USA (62.7\%), followed by the UK (9.5\%), and Germany $(3.8 \%)$. Despite the tremendous efforts, regulators have approved only a few gene therapy products (excluding oncolytic virus products): in 2003, Gendicine, Ad which encodes a tumor suppressor gene (PT53) was approved in China for the treatment of solid malignant tumors [19], in 2011, Neovasculgen, a plasmid which encodes the vascular endothelial growth factor (VEGF) gene was approved in Russia for the treatment of peripheral arterial disease [20], and in 2012, Glybera, adeno-associated virus (AAV)

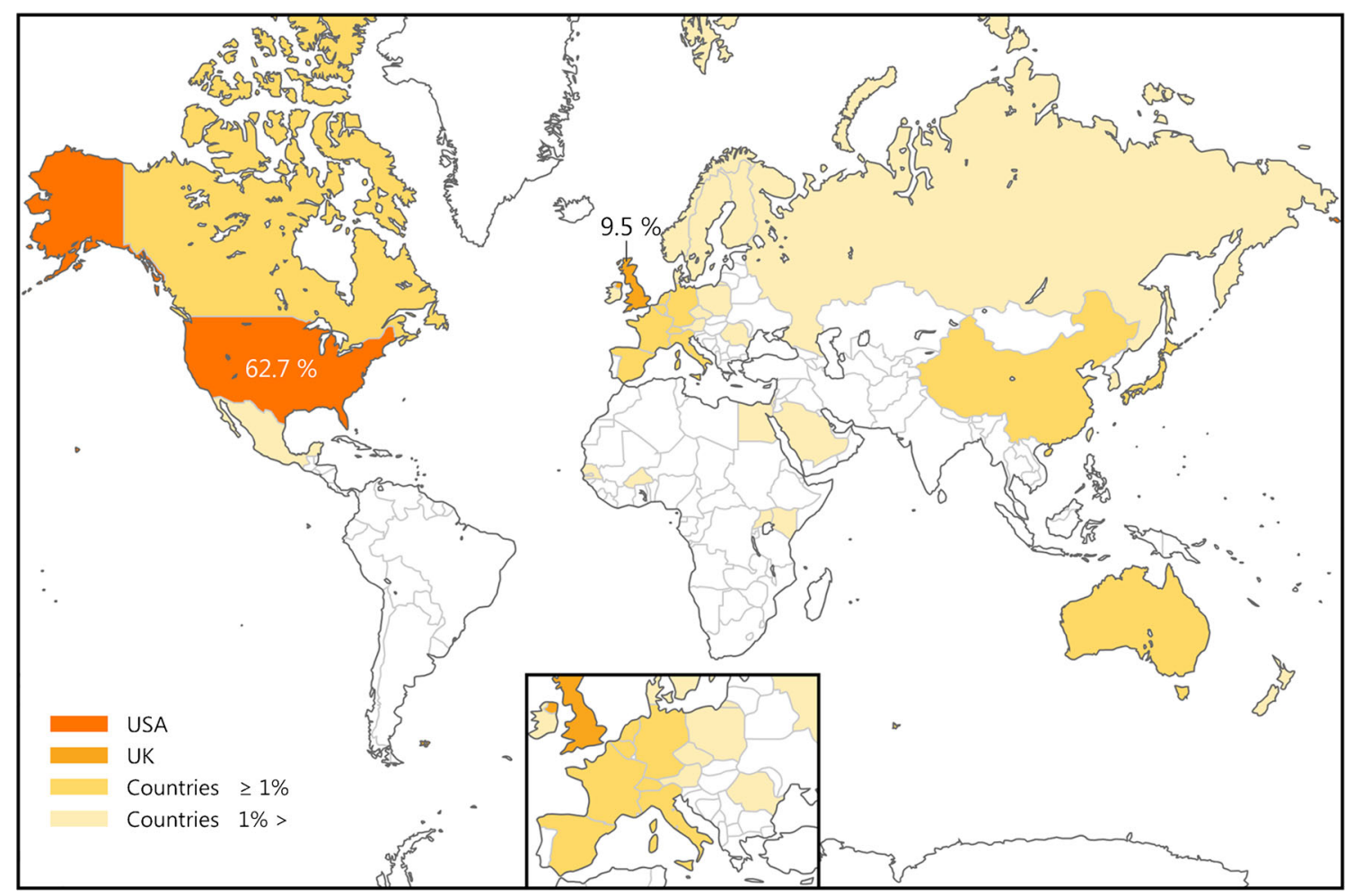

Fig. 1 The international landscape of gene therapy clinical trials (1989-2015). With permission by John Wiley \& Sons Ltd., the world map was drawn using the data of the 2210 trials that are archived in the Journal of Gene Medicine website [18] 
expressing $L P L$ was approved in the EU for the treatment of lipoprotein lipase deficiency [21]. One upcoming gene therapy product could be Strimvelis, autologous CD34+ cells with retrovirally transferred $A D A$ for ADA-SCID, which has been positively considered by the European Medicines Agency (EMA) [22]. However, there have been no gene therapy products that have been approved in the USA or other countries.

The delayed development is possibly due to two catastrophic events that occurred in the previous trials. One was the death of a volunteer due to acute inflammatory responses caused by the infusion of Ad vector in vivo gene therapy for ornithine transcarbamylase deficiency [23]. Of note, the tragedy was not directly associated with the transferred gene. The other was the death of a volunteer among infants who received ex vivo gene therapy for X-linked SCID [24]. Astonishingly, of the ten infants who received retrovirally $I L 2 R G$-transduced CD34+ cells, four developed T cell leukemia as late as 31-68 months after infusion. A subsequent investigation concluded that the subjects developed leukemia due to insertional mutagenesis near proto-oncogenes such as LMO2, BMI1, and CCND2. Such tragedies underscore the need for the careful assessment of the risks associated with gene transfer, as well as a follow-up period of at least 5 years after gene therapy.

\section{Genome Editing for Disease Treatments}

ZFNs and TALENs are bacterial Fok I nucleases which are fused with the DNA-binding domains that are custom-made to target a specific gene in the genome [7, 8]. The CRISPR/Cas9 system uses bacterial Cas9 nucleases guided by separate RNA, not a full protein system [9, 10]. Genome editing begins with the induction of DNA double-strand break (DSB) at a target site(s) with the introduction of designed nucleases in the form of DNA, mRNA, or protein (ribonucleoprotein in the case of CRISPR/Cas9 [25]). Subsequently, it efficiently disrupts an endogenous gene via non-homologous end joining (NHEJ) or copies a variant or adds a transgene via homologydirected repair (HDR). The efficiency of genome editing is extremely high. For instance, ZFNs delivered by Ad vector efficiently induced CCR5 disruption via NHEJ in approximately $50 \%$ of primary human CD4+ T cells [26]. The introduction of ZFN mRNA with a donor template by an AAV vector attained efficient genome editing in human HSCs via HDR, with the site-specific insertion of a GFP cassette at the CCR 5 and AAVS1 loci at mean frequencies of 17 and $26 \%$, respectively [27•]. Moreover, the targeted insertion of the tissue plasminogen activator (TPA) gene at the AAVS1 locus via HDR was effective in $81 \%$ of human MSCs [28]. With regard to multiplex genome editing, CRISPR/Cas9 is advantageous over ZFNs and TALENs, in that it readily allows the introduction of multiple guide RNAs (gRNAs) [11].
There are still some technical problems related to the clinical use of genome editing. Chief among them is the potential for off-target effects that may be caused by inappropriately designed nucleases. This can lead to the creation of base insertions or deletions (indels) at non-target sites in the genome [7-9, 14, 29]. The genetic changes might result in serious side effects, including cancer, due to mechanisms such as oncogene activation or the disruption of tumor suppressor genes.

Table 1 shows the completed or ongoing clinical trials and the therapy. All the clinical trials are conducted in the USA where gene therapy has actively been developed (Fig. 1). Of note, no healthy volunteers were recruited in the clinical trials, which differ from drug developments. With the versatility and robustness of genetic modification, genome editing is expected to provide myriad therapeutic benefits for patients with genetic diseases. Nonetheless, the first use was not associated with monogenic or polygenic diseases. In the phase 1 trial, CCR5 in autologous CD4+ T cells was "disrupted" by delivering Ad-ZFN in order to develop an ex vivo editing therapy for patients with HIV infection (NCT00842634) [12••]. This is based on a clinical case in which an HIV patient went into remission after receiving HSCs with a naturally occurring variant, $C C R 5 \Delta 32$ (the so-called Berlin patient) [30]. As a result of the phase 1 study, the safety of the infusion of CCR5-disrupted T cells was demonstrated, despite one serious adverse event due to a transfusion reaction. However, the occurrence of off-target mutations was not investigated in the ZFN-treated T cells [12••]. In the preclinical research, the probability of off-target mutations was determined to be $5.39 \%$ in $C C R 2$ and $\sim 1 / 20,000$ in $A B L I M 2$, which is considered to be clinically tolerable [26]. Nonetheless, the onset of leukemia in the previous gene therapy trial for X-SCID urges us to genetically characterize the cells that are modified for transplantation as much as possible [24]. In contrast, multiple clinical trials of this HIV therapy have been ongoing, with the escalation of the T cell dose (NCT01044654) and the cyclophosphamide dose (NCT01543152). More recently, three similar clinical trials, which have adopted electroporation with ZFN mRNA, have been initiated (NCT02225665, 02388594, 02500849) [27•]. Of note, one of the three uses autologous HSCs, not T cells (NCT02500849). ZFNCCR5-HSCs might provide complete remission to HIVpositive patients, similar to the "Berlin patient."

Gene disruption was adopted in another ex vivo editing therapy for an infant with terminal ALL (Table 1) [13]. This was a special therapy, rather than a clinical trial, and was approved by IRB and a UK regulator. The therapy had three characteristics. First, it involved allogenic not autologous CAR19 T cell transplantation. Second, it used multiplex genome editing. Two genes in CAR19 T cells were simultaneously disrupted by TALEN treatment. Namely, the 
Table 1 Clinical applications of genome editing

\begin{tabular}{|c|c|c|c|c|c|}
\hline $\begin{array}{l}\text { Clinical trial or treatment } \\
\text { (year) }\end{array}$ & Sponsor & Condition & Intervention & Study design & Trial ID \\
\hline $\begin{array}{l}\text { Ex vivo editing: } \\
\text { phase } 1 \\
(2009-2013)\end{array}$ & $\begin{array}{l}\text { University of } \\
\text { Pennsylvania } \\
\text { (USA) }\end{array}$ & HIV & $\begin{array}{l}\text { Infusion of autologous } \\
\text { CD4+ T cells modified } \\
\text { at CCR } 5 \text { by ZFN, with } \\
\text { interruption of antiretroviral } \\
\text { treatment }\end{array}$ & $\begin{array}{l}\text { Non-randomized. } \\
\text { Open label. } \\
12 \text { patients enrolled. } \\
\text { ZFN delivered by } \\
\text { adenoviral vector. }\end{array}$ & $\begin{array}{l}\text { NCT } \\
00842634\end{array}$ \\
\hline $\begin{array}{l}\text { Ex vivo editing: } \\
\text { phase } 1 \\
(2009-2014)\end{array}$ & $\begin{array}{l}\text { Sangamo } \\
\text { Biosciences } \\
\text { (USA) }\end{array}$ & HIV & $\begin{array}{l}\text { Dose escalation of } \\
\text { autologous CD4+ } \\
\text { T cells modified at } \\
\text { CCR5 by ZFN }\end{array}$ & $\begin{array}{l}\text { Non-randomized. } \\
\text { Open label. } \\
19 \text { patients enrolled. } \\
\text { ZFN delivered by } \\
\text { adenoviral vector. }\end{array}$ & $\begin{array}{l}\text { NCT } \\
01044654\end{array}$ \\
\hline $\begin{array}{l}\text { Ex vivo editing: } \\
\text { phases } 1 \text { and } 2 \\
(2011)\end{array}$ & $\begin{array}{l}\text { Sangamo } \\
\text { Biosciences } \\
\text { (USA) }\end{array}$ & HIV & $\begin{array}{l}\text { Dose escalation of } \\
\text { cyclophosphamide } \\
\text { in patients receiving autologous } \\
\text { CD4+ } \\
\text { T cells modified at CCR } 5 \text { by ZFN }\end{array}$ & $\begin{array}{l}\text { Non-randomized. } \\
\text { Open label. } \\
\text { Patient enrollment: } \\
\text { 26. ZFN delivered by } \\
\text { adenoviral vector. }\end{array}$ & $\begin{array}{l}\text { NCT } \\
01543152\end{array}$ \\
\hline $\begin{array}{l}\text { Ex vivo editing: } \\
\text { phases } 1 \text { and } 2 \\
\text { (2014) }\end{array}$ & $\begin{array}{l}\text { Sangamo } \\
\text { Biosciences } \\
\text { (USA) }\end{array}$ & HIV & $\begin{array}{l}\text { Repeat doses of autologous CD4+ } \\
\text { T cells modified at CCR5 by } \\
\text { ZFN following } \\
\text { cyclophosphamide } \\
\text { conditioning }\end{array}$ & $\begin{array}{l}\text { Non-randomized. } \\
\text { Open label. } \\
\text { Patient enrollment: } \\
\text { 12. Cells electroporated } \\
\text { with ZFN mRNA. }\end{array}$ & $\begin{array}{l}\text { NCT } \\
02225665\end{array}$ \\
\hline $\begin{array}{l}\text { Ex vivo editing: } \\
\text { phase } 1 \text { (2015) }\end{array}$ & $\begin{array}{l}\text { University of } \\
\text { Pennsylvania } \\
\text { (USA) }\end{array}$ & HIV & $\begin{array}{l}\text { Infusion of autologous CD4+ T cells } \\
\text { modified at CCR5 by ZFN with } \\
\text { or } \\
\text { without prior administration of } \\
\text { cyclophosphamide }\end{array}$ & $\begin{array}{l}\text { Non-randomized. } \\
\text { Open label. } \\
\text { Patient enrollment: } 15 . \\
\text { ZFN mRNA } \\
\text { electroporated. }\end{array}$ & $\begin{array}{l}\text { NCT } \\
02388594\end{array}$ \\
\hline $\begin{array}{l}\text { Ex vivo editing: } \\
\text { phase } 1(2015)\end{array}$ & $\begin{array}{l}\text { City of Hope } \\
\text { Medical } \\
\text { Center } \\
\text { (USA) }\end{array}$ & HIV & $\begin{array}{l}\text { Infusion of autologous CD34+ } \\
\text { hematopoietic stem/progenitor } \\
\text { cells modified at CCR5 by ZFN } \\
\text { following busulfan conditioning }\end{array}$ & $\begin{array}{l}\text { Non-randomized. } \\
\text { Open label. } \\
\text { Patient enrollment: } \\
\text { 12. Cells electroporated } \\
\text { with ZFN mRNA. }\end{array}$ & $\begin{array}{l}\text { NCT } \\
02500849\end{array}$ \\
\hline $\begin{array}{l}\text { In vivo editing: } \\
\text { phase } 1(2016)\end{array}$ & $\begin{array}{l}\text { Sangamo } \\
\text { Biosciences } \\
\text { (USA) }\end{array}$ & HB & $\begin{array}{l}\text { Intravenously delivery of } \\
\text { ZFN-AAV } 2 / 6 \\
\text { to insert a correct copy of } \\
\text { FIX into the albumin locus in } \\
\text { hepatocytes }\end{array}$ & $\begin{array}{l}\text { Non-randomized. } \\
\text { Open label. } \\
\text { Patient enrollment: } 9 .\end{array}$ & $\begin{array}{l}\text { NCT } \\
02695160\end{array}$ \\
\hline $\begin{array}{l}\text { In vivo editing: } \\
\text { phase } 1(2016)\end{array}$ & $\begin{array}{l}\text { Sangamo } \\
\text { Biosciences } \\
\text { (USA) }\end{array}$ & MPS I & $\begin{array}{l}\text { Intravenously delivery of } \\
\text { ZFN-AAV2/6 } \\
\text { to insert a correct copy of } \\
\text { IDUA into the albumin } \\
\text { locus in hepatocytes }\end{array}$ & $\begin{array}{l}\text { Non-randomized. } \\
\text { Open label. } \\
\text { Patient enrollment: } 9 .\end{array}$ & $\begin{array}{l}\text { NCT } \\
02702115\end{array}$ \\
\hline $\begin{array}{l}\text { Ex vivo editing: } \\
\text { special therapy } \\
(2015)\end{array}$ & $\begin{array}{l}\text { Great Ormond } \\
\text { Street Hospital } \\
\text { (UK) }\end{array}$ & ALL & $\begin{array}{l}\text { Infusion of allogous CAR19 T cells } \\
\text { further modified at TCR and } \\
\text { CD52 by TALEN }\end{array}$ & $\begin{array}{l}\text { One patient treated. } \\
\text { Cells electroporated } \\
\text { with TALEN mRNA. }\end{array}$ & $\begin{array}{l}\text { MHRA special } \\
\text { license }\end{array}$ \\
\hline
\end{tabular}

Relevant clinical trials were surveyed using ClinicalTrials.gov. The status is on April 1, 2016

$H I V$ human immunodeficiency virus, $H B$ hemophilia B, MPS I mucopolysaccharidosis I, $A L L$ acute lymphoid leukemia

disruption of the T cell receptor alpha constant chain locus was performed with the intention of preventing the onset of GVHD. The disruption of the CD52 locus can render the T cells insensitive to lymphodepleting agents. Third, the infusion of highly modified T cells successfully led to the patient's remission. It is unclear whether the genetically modified CAR19 T cells were investigated for possible off-target mutations, However, the preclinical study reported that the highest frequency of indels at the potential off-targets was only 1 in $8 \times 10^{-4}$ in TCR/CD52-disrupted CAR T cells [31 ${ }^{\bullet}$. Taken together, genome editing might maximize the therapeutic potential of CAR19 T cells in the treatment of leukemia if further clinical trials demonstrate their safety and efficacy.

In vivo editing therapies have been studied for the treatment of hemophilia B (HB) and mucopolysaccharidosis I (MPS I) $[32,33]$. Such phase 1 studies are currently being performed using ZFNs (Table 1: NCT02695610, 02702115). In such studies, exogenous complement gene $(F I X)$ and alpha-Liduronidase gene (IDUA) are transferred into hepatocytes with intravenously delivered AAV vector which is also adopted in 
Glybera. Interestingly, such WT genes are inserted at the albumin locus as a genomic safe harbor [34]. If such studies demonstrate the safety in vivo editing therapies involving gene addition are likely to be considered for other hepatopathies. The candidates include Wilson's disease (ATP7B mutations) [35], hemochromatosis (HFE mutations) [36], and porphyria (which includes $A L A D, A L A S 2$, and CPOX mutations) [37]. Other than hepatocytes, muscle and muscle stem cells may be candidates as target cells for in vivo editing therapy. Three mouse studies elegantly demonstrated that the delivery of two gRNAs-guided Cas9s by an AAV vector can skip a frame-disrupting mutation in the $D M D$ that is responsible for Duchenne muscular dystrophy [38-40]. The gene correction restored $D M D$ expression in muscle and muscle stem cells. Moreover, the correction of the DMD mutation partially ameliorated the muscle function deficiencies in the animals.

More lines of genome editing therapy will be developed. However, there are some questions regarding the paths to regulatory approval because genome-editing medicine entails the unprecedented introduction of artificially designed nucleases into the patient's cells or body [14]. Will regulators view gene disruption therapy negatively? It might seem an unorthodox form of gene therapy. However, regulators will likely focus on whether the gene disruption is based on clinical evidence, as illustrated by the US FDA approval of multiple clinical trials in which CCR5 in CD4+ T cells is disrupted in order to mimic the "Berlin patient" [30] (Table 1). In addition, the risk surrounding gene disruption in ex vivo editing therapy can, to some extent, be assessed in vitro. In vivo genome editing needs more rigorous criteria for risk assessment because it directly introduces artificially designed nucleases into the patient's body. Another question is how regulators will view multiplex genome editing. Although the risk of offtarget mutations might increase in multiplex genome editing, a regulator's view would depend on the scientific evidence shown by the preclinical study. Next, will regulators approve genome-editing medicine in the near future? The answer for at least the next decade, is likely to be "no" because the most advanced stage in clinical development is still phase 2, for two ex vivo editing therapy trials for HIV patients in the USA (Table 1). Further clinical studies recruiting more patients may thus be required to assess its efficacy in the treatment of HIV infection. However, a rare disease (orphan) designation could accelerate its development since it took only about 8 years from the orphan designation of Glybera for it to receive EMA approval [21]. This regulatory path is also applicable in some countries other than European countries. Then, would an orphan designation truly shorten the development period in the USA where most of relevant clinical trials are underway? It is difficult to answer because the US FDA has rejected orphan-designated Advexin, which is a cancer gene therapy product similar to Gendicine [21], and has not approved any gene therapy products to date. Although the
International Conference on Harmonisation of Technical Requirements for Registration of Pharmaceuticals for Human Use ( $\mathrm{ICH})$ which brings together the regulatory authorities and the pharmaceutical industry of Europe, Japan, and the USA has developed some consideration documents regarding gene therapy [41], more regulatory harmonization is indispensable in order to maximize the therapeutic benefits of genome editing worldwide.

\section{Issues Arising from the Widespread Use of Genome Editing}

With the further development of genome-editing medicine, some issues are likely to occur domestically or internationally due to the widespread use as well as the ease of genetic modification particularly in CRISPR/Cas9 [42]. The potential ethical issues are herein considered in order to appropriately integrate genome editing into medicine.

Unproven somatic editing therapies might be advertised by showing only the efficiency of gene modification and its effectiveness, without providing any information about their potential risks [43]. Of course, this is strictly prohibited in the USA (21 U.S.C. 352[n]), the EU (Council Directive 92/ 28/EEC), Japan (Law for Ensuring the Quality, Efficacy, and Safety of Drugs and Medical Devices), and other jurisdictions. Nonetheless, the possibility of the illegal advertisements should be considered based on the problems surrounding stem cell therapy in the USA, the UK, Japan, Germany, Mexico, China, and Russia and other countries [44, 45].

Some genome-editing therapy products will be approved for marketing in a country. In the future, there are many such products that could be developed due to the number of genetic conditions: there are more than 10,000 monogenic diseases alone [46]. Notably, the world's most expensive medicine is likely to be Glybera (presumed total cost required for treating of one patient: $€ 1.1$ million) [47]. If the cost of genome-editing products is similar to that of Glybera, the medical benefits would be confined to the wealthier segment and would not be covered by public medical insurance. Meanwhile, some argue that Glybera is cost-effective [48]. However, it is unclear whether a society can afford numerous products with a similar level of cost in the current social health insurance system.

When genome-editing therapy is available in a country, foreign people can also access the information via the internet. They sometimes visit the country to undergo treatment, likely creating medical tourism [43]. Medical tourism may be acceptable if the offered medicine is appropriately regulated in the country. However, unfavorable medical tourism could occur in countries with lax regulations. This concern is no longer theoretical. Some stem cell clinics advertise anti-aging treatments without insufficient information on their websites [45]. 
In addition, anti-aging gene therapy is planned to be offered to visitors of South America [49].

Moreover, genome-editing therapy might be provided in a country before the regulators can assess its safety and efficacy and approve its marketing. Indeed, some Japanese physicians import Gendicine which has been approved in China, but not in Japan, and offer it to cancer patients in Japan, despite its cost being higher than that of the standard treatments [50]. If physicians observe the Medical Practitioners' Act as well as the Medical Care Act, it is legal to provide such medical products as free medical care which is not covered by Japanese universal health care system. However, the provision of genome-editing therapy is, at present, unacceptable since no genome-editing therapies have been approved worldwide (Table 1).

One unfavorable application of genome editing would be to abuse it for gaining advantage in an athletic competition. For instance, it is well known that a cross country skier who won three Olympic gold medals had an erythropoietin receptor gene, EPOR variant that is observed in familial and congenital polycythemia (PFCP). This naturally occurring variant largely increases erythrocyte mass and hemoglobin [51]. For this reason, it is conceivable that the editing EPOR gene might allow for an individual to gain an advantage in endurance competitions. In contrast, the World Anti-Doping Agency (WADA) defines gene doping as "the nontherapeutic use of cells, genes, genetic elements, or of the modulation of gene expression, having the capacity to improve athletic performance." According to this definition, genome editingmediated gene doping is not allowed in the world of sports. However, it appears that it would to be difficult to recognize the violation, even if the EPOR variant can be successfully detected. An athlete could assert that she or he has originally had the variant.

Another controversial use is to pursue beauty according to one's aesthetic sense. White skin might be attainable by disrupting genes associated with pigmentation [52]. It is true that cosmetic surgery is offered for "patients" who pursue mental and social well-being and who consent to potential health risks, but cosmetic treatment involving genome editing would not be free from the risk of off-target mutations. The risk-benefit balance does not warrant such a use of genome editing in clinics. However, to seek cosmetic enhancement, some people might treat themselves by do-it-yourself genome editing [53].

The versatility and robustness of genome editing are therefore expected to positively contribute to the development of novel disease treatments, whereas the characteristics could also lead to some unfavorable social phenomena. The public must sufficiently understand the fact that only a few gene therapy products have been approved by health regulators worldwide. Moreover, all citizens should be provided accurate information regarding the development of somatic editing therapy.

\section{Conclusions}

Although there is great promise for somatic genome editing in the future of medicine, the regulatory approval will not be granted in the short term. One of the major obstacles is that there is no clear consensus regarding the extent to which offtarget effects should be detected in clinical applications [29]. If researchers truly wish to provide the medical benefits associated with genome editing, then they should closely cooperate with regulators to establish the guidelines for assessing the off-target effects of ex vivo and in vivo somatic editing therapies, which will thereby foster an increase in worldwide regulatory harmonization.

The WHO defines health as a state of complete physical, mental, and social well-being and not merely the absence of disease or infirmity. At present, it is socially undesirable or impermissible to use somatic genome editing for any purposes other than the treatment of disease. However, stricter regulations should not be placed on somatic editing therapy for unmet medical needs. Instead, it is crucial to inform people in the world about the risks and benefits in addition to accurate information regarding the clinical development. The social norms of genome editing should be steadily formed through public dialogues to shape the appropriate roles in global society.

Acknowledgments I express my gratitude for the valuable discussions in an online forum: @ NEJM Ask the Authors \& Experts: On the Road (to a Cure?): Stem Cell Tourism and Lessons for Gene Editing, which was organized by the New England Journal of Medicine (https://medstro. $\mathrm{com} /$ groups/nejm-group-open-forum/discussions/226). This work was supported by the Japan Society for the Promotion of Science (JSPS) KAKENHI grant 26460586 (T.I.).

\section{Compliance with Ethical Standards}

Conflict of Interest Tetsuya Ishii declares no conflicts of interest.

Human and Animal Rights and Informed Consent This article does not contain any studies with human or animal subjects performed by any of the authors.

\section{References}

Papers of particular interest, published recently, have been highlighted as:

- Of importance

-• Of major importance

1. Gratwohl A, Baldomero H, Aljurf M, et al. Hematopoietic stem cell transplantation: a global perspective. JAMA. 2010;303(16):161724. doi:10.1001/jama.2010.491. 
2. Blazar BR, Murphy WJ, Abedi M. Advances in graft-versushost disease biology and therapy. Nat Rev Immunol. 2012;12(6):443-58.

3. Trounson A, McDonald C. Stem cell therapies in clinical trials: progress and challenges. Cell Stem Cell. 2015;17(1):11-22. doi:10.1016/j.stem.2015.06.007.

4. Hatada S, Nikkuni K, Bentley SA, Kirby S, Smithies O. Gene correction in hematopoietic progenitor cells by homologous recombination. Proc Natl Acad Sci U S A. 2000;97(25):13807-11. doi:10.1073/pnas.240462897.

5. Zwaka TP, Thomson JA. Homologous recombination in human embryonic stem cells. Nat Biotech. 2003;21(3):319-21.

6. Thomas CE, Ehrhardt A, Kay MA. Progress and problems with the use of viral vectors for gene therapy. Nat Rev Genet. 2003;4(5): 346-58.

7. Klug A. The discovery of zinc fingers and their applications in gene regulation and genome manipulation. Annu Rev Biochem. 2010;79:213-31. doi:10.1146/annurev-biochem-010909-095056.

8. Joung JK, Sander JD. TALENs: a widely applicable technology for targeted genome editing. Nat Rev Mol Cell Biol. 2013;14(1):49-55 http://www.nature.com/nrm/journal/v14/n1/suppinfo/nrm3486_S1. html.

9. Hsu PD, Lander ES, Zhang F. Development and applications of CRISPR-Cas9 for genome engineering. Cell. 2014;157(6):126278. doi:10.1016/j.cell.2014.05.010.

10. Wright AV, Nunez JK, Doudna JA. Biology and applications of CRISPR systems: harnessing nature's toolbox for genome engineering. Cell. 2016;164(1-2):29-44. doi:10.1016/j. cell.2015.12.035.

11. Cong L, Ran FA, Cox D, Lin S, Barretto R, Habib N, et al. Multiplex genome engineering using CRISPR/Cas systems. Science (New York, NY). 2013;339(6121):819-23. doi:10.1126/science.1231143.

12.• Tebas P, Stein D, Tang WW, Frank I, Wang SQ, Lee G, et al. Gene editing of CCR5 in autologous CD4 T cells of persons infected with HIV. N Engl J Med. 2014;370(10):901-10. doi:10.1056 /NEJMoa1300662 .This first-in human study demonstrated the safety of CD4 $\mathrm{T}$ cells in which a gene was disrupted by genome editing, paving the way for further clinical trials for treating HIV infection.

13. Qasim W, Jal Amrolia S, Samarasinghe S, Ghorashian S, Zhan H, Stafford $\mathrm{S}$ et al. First clinical application of Talen Engineered Universal CAR19 T Cells in B-ALL. American Socity of Hematology 57th Annual Meediting\&Exposition; December 5, 2015; Orland, FL 2015.

14. Araki M, Ishii T. Providing appropriate risk information on genome editing for patients. Trends Biotechnol. 2016;34(2):86-90. doi:10.1016/j.tibtech.2015.12.002.

15. Li AP. Screening for human ADME/Tox drug properties in drug discovery. Drug Discov Today. 2001;6(7):357-66.

16. Ishii T. Germ line genome editing in clinics: the approaches, objectives and global society. Brief Funct Genomics. 2015. doi:10.1093 /bfgp/elv053.

17. Blaese RM, Culver KW, Miller AD, Carter CS, Fleisher T, Clerici $\mathrm{M}$, et al. T lymphocyte-directed gene therapy for ADA- SCID: initial trial results after 4 years. Science (New York, NY). 1995;270(5235):475-80.

18. The_Journal_of_Gene_Medicine. Gene therapy clinical trials worldwide. http://www.abediacom/wiley/countriesphp. Accessed 11 May 2016.

19. Li Y, Li B, Li CJ, Li LJ. Key points of basic theories and clinical practice in rAd-p53 (Gendicine) gene therapy for solid malignant tumors. Expert Opin Biol Ther. 2015;15(3):437-54. doi:10.1517/14712598.2015.990882.

20. Chervyakov YV, Staroverov IN, Vlasenko ON, Nersesyan EG, Isaev AA, Deev RV. Remote results of treatment of patients with chronic lower-limb ischaemia by means of indirect revascularization and gene therapy. Angiologiia i sosudistaia khirurgiia $=$ Angiology and vascular surgery. 2016;22(1):29-34 67.

21. Watanabe N, Yano K, Tsuyuki K, Okano T, Yamato M. Reexamination of regulatory opinions in Europe: possible contribution for the approval of the first gene therapy product Glybera. Mol Ther Methods Clin Dev. 2015;2:14066. doi:10.1038/mtm.2014.66.

22. European_Medicines_Agency. New gene therapy for the treatment of children with ultra-rare immune disorder recommended for approval Orphan-designated Strimvelis to offer treatment option for patients with ADA-SCID who have no suitable stem cell donor. $\mathrm{http}: / /$ www.emaeuropaeu/ema/indexjsp?curl $=$ pages/news and events/news/2016/04/news detail 002504jsp\&mid = WC̄0b01 ac058004d5c1. Accessed 19 April 2016.

23. Barbour V. The balance of risk and benefit in gene-therapy trials. Lancet (London, England). 2000;355(9201):384. doi:10.1016/s0140-6736(05)74011-3.

24. Hacein-Bey-Abina S, Garrigue A, Wang GP, Soulier J, Lim A, Morillon $\mathrm{E}$, et al. Insertional oncogenesis in 4 patients after retrovirus-mediated gene therapy of SCID-X1. J Clin Invest. 2008;118(9):3132-42. doi:10.1172/jci35700.

25. Kim S, Kim D, Cho SW, Kim J, Kim JS. Highly efficient RNA-guided genome editing in human cells via delivery of purified Cas9 ribonucleoproteins. Genome Res. 2014;24(6): 1012-9. doi:10.1101/gr.171322.113.

26. Perez EE, Wang J, Miller JC, Jouvenot Y, Kim KA, Liu O, et al. Establishment of HIV-1 resistance in CD4+ T cells by genome editing using zinc-finger nucleases. Nat Biotechnol. 2008;26(7): 808-16. doi:10.1038/nbt1410.

27. Wang J, Exline CM, DeClercq JJ, Llewellyn GN, Hayward SB, Li PW, et al. Homology-driven genome editing in hematopoietic stem and progenitor cells using ZFN mRNA and AAV6 donors. Nat Biotechnol. 2015;33(12):1256-63. doi:10.1038/nbt.3408 .This research shows that $\mathrm{ZFN}$ treatment can achieve efficient sitespecific insertion of an exogenous gene in human long-term repopulating cell population, which will lead to the development of treatments effective for a prolonged period of time

28. Li SJ, Shi RZ, Bai YP, Hong D, Yang W, Wang X, et al. Targeted introduction of tissue plasminogen activator (TPA) at the AAVS1 locus in mesenchymal stem cells (MSCs) and its stable and effective expression. Biochem Biophys Res Commun. 2013;437(1):74 8. doi:10.1016/j.bbrc.2013.06.037.

29. Joung JK. Unwanted mutations: standards needed for gene-editing errors. Nature. 2015;523(7559):158. doi:10.1038/523158a.

30. Hutter G, Nowak D, Mossner M, Ganepola S, Mussig A, Allers K, et al. Long-term control of HIV by CCR5 Delta32/Delta32 stemcell transplantation. N Engl J Med. 2009;360(7):692-8. doi:10.1056/NEJMoa0802905.

31. Poirot L, Philip B, Schiffer-Mannioui C, Le Clerre D, ChionSotinel I, Derniame S, et al. Multiplex genome-edited T-cell manufacturing platform for "off-the-shelf" adoptive T-cell immunotherapies. Cancer Res. 2015;75(18):3853-64. doi:10.1158/0008-5472.can-14-3321. This study demonstrated the applicability of TALEN-mediated genome editing to the manufacturing of third-party CAR Tcell immunotherapy.

32. Li H, Haurigot V, Doyon Y, Li T, Wong SY, Bhagwat AS, et al. vivo genome editing restores haemostasis in a mouse model of haemophilia. Nature. 2011;475(7355):217-21. doi:10.1038 /nature10177.

33. Sharma R, Anguela XM, Doyon Y, Wechsler T, DeKelver RC, Sproul S, et al. vivo genome editing of the albumin locus as a platform for protein replacement therapy. Blood. 2015;126(15): 1777-84. doi:10.1182/blood-2014-12-615492. 
34. Sadelain M, Papapetrou EP, Bushman FD. Safe harbours for the integration of new DNA in the human genome. Nature reviews. Cancer. 2012;12(1):51-8. doi:10.1038/nrc3179.

35. Ala A, Walker AP, Ashkan K, Dooley JS, Schilsky ML. Wilson's disease. Lancet (London, England). 2007;369(9559):397-408. doi:10.1016/s0140-6736(07)60196-2.

36. Pietrangelo A. Hereditary hemochromatosis - a new look at an old disease. N Engl J Med. 2004;350(23):2383-97. doi:10.1056/NEJMra031573.

37. Puy H, Gouya L, Deybach JC. Porphyrias. Lancet (London, England). 2010;375(9718):924-37. doi:10.1016/s0140-6736 (09)61925-5.

38. Long C, Amoasii L, Mireault AA, McAnally JR, Li H, SanchezOrtiz E, et al. Postnatal genome editing partially restores dystrophin expression in a mouse model of muscular dystrophy. Science (New York, NY). 2016;351(6271):400-3. doi:10.1126/science.aad5725.

39. Nelson CE, Hakim CH, Ousterout DG, Thakore PI, Moreb EA, Castellanos Rivera RM, et al. In vivo genome editing improves muscle function in a mouse model of Duchenne muscular dystrophy. Science (New York, NY). 2016;351(6271):403-7. doi:10.1126/science.aad5143.

40. Tabebordbar M, Zhu K, Cheng JK, Chew WL, Widrick JJ, Yan WX, et al. In vivo gene editing in dystrophic mouse muscle and muscle stem cells. Science (New York, NY). 2016;351(6271):40711. doi:10.1126/science.aad5177.

41. International Conference on Harmonisation of Technical Requirements_for_Registration_of_Pharmaceuticals_for_Human_Use_(ICH). Consideration Documents by ICH Gene Therapy Discussion Group. http://www.ichorg/products/considerationdocumentshtml. Accessed 11 May 2016.

42. Ledford H. CRISPR, the disruptor. Nature. 2015;522(7554):20-4. doi:10.1038/522020a.
43. Charo RA. On the road (to a cure?)-stem-cell tourism and lessons for gene editing. N Engl J Med. 2016;374(10):901-3. doi:10.1056/NEJMp1600891.

44. Liang BA, Mackey TK. Stem cells, dot-com. Sci Transl Med. 2012;4(151):151cm9. doi:10.1126/scitranslmed.3004030.

45. Connolly R, O’Brien T, Flaherty G. Stem cell tourism \&\#×2013; a web-based analysis of clinical services available to international travellers. Travel Med Infect Dis. 12(6):695-701. doi:10.1016/j. tmaid.2014.09.008.

46. WHO. Genes and human disease: monogenic diseases. http://www. whoint/genomics/public/geneticdiseases/en/index $2 \mathrm{html}$. Accessed 19 April 2016.

47. Yla-Herttuala S. Glybera's second act: the curtain rises on the high cost of therapy. Mol Ther. 2015;23(2):217-8. doi: $10.1038 / \mathrm{mt} .2014 .248$

48. Han X, Ni W. Cost-effectiveness analysis of Glybera for the treatment of lipoprotein lipase deficiency. Value Health. 2015;18(7):A756. doi:10.1016/j.jval.2015.09.2461.

49. Regalado A. A tale of do-it-yourself gene therapy in MIT technology review 2015. https:/www.technologyreviewcom/s/542371/atale-of-do-it-yourself-gene-therapy/ Accessed 19 Apr 2016.

50. Nakagawa S. Gene therapy (in Japanese). J Japan Pharmaceutical Wholesalers Association. 2015;37(6):10-7.

51. de la Chapelle A, Traskelin AL, Juvonen E. Truncated erythropoietin receptor causes dominantly inherited benign human erythrocytosis. Proc Natl Acad Sci U S A. 1993;90(10):4495-9.

52. Kamaraj B. Purohit R. Mutational analysis of oculocutaneous albinism: a compact review. 2014;2014:905472. doi:10.1155/2014/905472.

53. Ledford H. Biohackers gear up for genome editing. Nature. 2015;524(7566):398-9. doi:10.1038/524398a. 